\title{
The Dayah Ulama's Views on Plurality and Tolerance in Aceh
}

\author{
Syarifuddin \\ Universitas Islam Negeri (UIN) Ar-Raniry \\ syarifuddinab@ar-raniry.ac.id
}

\begin{abstract}
Dayah 'ulama' or teungku dayah occupy a unique position in Acehnese society. They are a source of reference in various religious issues and social issues that develop in society. As the founder and manager of the dayah, traditional Islamic education institutions, the 'ulama' or teungku dayah have cultural power in shaping and coloring the community's knowledge and religious understanding. Therefore, their views regarding plurality and tolerance in Aceh are relevant to be studied to see one fragment in the opinions and attitudes of the 'ulama' or tengku and Acehnese society regarding diversity in Aceh. In general, the 'ulama' or teungku dayah interviewed in this study gave a complimentary view of the reality of pluralism in the Acehnese community both in terms of inter-religious and intra-Muslim relations. However, they provide limitations regarding the aspects that can be tolerated and which should be prohibited.
\end{abstract}

Keywords: 'Ulama', Dayah, Plurality, Tolerance, and Aceh

Abstrak. Ulama dayah atau Teungku Dayah menempati posisi istimewa di tengah masyarakat Aceh. Mereka adalah sumber rujukan dalam berbagai persoalan keagamaan dan isu-isu sosial yang berkembang di masyarakat. Sebagai pendiri maupun pengelola dayah, lembaga pendidikan Islam tradisional, para ulama atau teungku dayah memiliki kuasa kultural dalam membentuk dan mewarnai pengetahuan dan paham keagamaan masyarakat. Karena itu, pandangan-pandangan mereka terkait isu-isu pluralitas dan toleransi di Aceh relevan untuk dikaji guna melihat salah satu fragmen dalam pandangan dan sikap para ulama atau tengku serta masyarakat Aceh terkait keragaman di Aceh. Secara umum, para ulama atau teungku dayah yang diwawancari dalam 
penelitian ini memberikan pandangan positif tentang realitas kemajemukan di tengah masyarakat Aceh baik dalam hubunga antarumat beragama dan intraumat Islam. Namun demikian, mereka memberikan batasan-batasan mengenai aspek-aspek yang dapat ditoleransi dan yang perlu dilarang.

Kata Kunci: Ulama, Dayah, Pluralitas, Toleransi dan Aceh

\section{Introduction}

$\mathrm{P}$

lurality is the reality of society in Aceh. Aceh consists of many indigenous ethnicities, each of which is divided. Acehnese are the largest ethnic group followed by Gayo ethnicity (Gayo Lut, Luwes and Sabejadi), Jamee ethnicity, Singkil ethnicity, Pakpak ethnicity, Alas ethnicity, Kluet ethnicity, Tamiang ethnicity, and Sigulai ethnicity. Apart from the original ethnicity, other ethnicities live in Aceh, such as Javanese, Minangkabau, Sundanese, including Hakka (one of the Chinese ethnic groups). All of these ethnic groups speak different languages outside Indonesian. In terms of religion, even though Islam is the majority religion in Aceh, Christianity, Catholicism, Hinduism, Buddhism, and Confucianism are side by side in people's lives.

In the relationship between plurality and the management of tolerance, Aceh has often received the spotlight. Aceh is one of Indonesia's regions that has a very strong commitment and demands to the application of Islamic law in the political system and government. This demand has been going on for a long time since the struggles to defend Indonesia's independence. The DI / TII (Darul Islam / Indonesian Islamic Army) rebellion led by Daud Beureueh in 1953 was motivated by disappointment over the merger of Aceh Province into North Sumatra Province and because of the demands for regional autonomy were not fulfilled for Aceh to implement Islamic shari'ah. The demand for the application of Islamic shari'ah in the political system and governance in Aceh was finally materialized through Law No. 44 of 1999 concerning the Special Region of Aceh's Implementation. Based on this law, Aceh Government in 2000 issued a regional regulation (qanun) Number 5 of 2002 concerning the Implementation of Islamic Sharia. The aspects covered in this regional regulation or qanun are aqidah, worship, muamalah, morals, education and Islamic da'wah / amar makruf nahi munkar, baitulmal, social, Islamic syiar, Islamic defense, qadha, jinayah, munakah, and mawaris (Abubakar, 2011, 99).

The formalization of Islamic shari'ah raises many further questions, especially about the existence and position of non-Muslim communities, freedom of religion, and relations between religious believers. When the discourse on formalizing Islamic shari'ah surfaced, non-Islamic religions' rights 
became a serious polemic in public regarding concerns about the castration of minority rights. Besides, the formalization of Islamic shari'ah also opens up questions regarding the source of the formation of shari'ah regulations or qanuns. In Aceh, most people and scholars of fiqh are Shafi'i, but that does not mean that there is no legal debate among followers of the Shafi'i school. Also, the formation of a positive rule of law based on the legal formula of the Shafi'i School means the institutionalization of one fiqh school and exclusion of other schools of thought.

The latter phenomenon has become a more prominent issue of tolerance in Aceh recently. This is because polemics, friction, and intra-Islamic friction are increasingly occurring, which is reflected in several cases of seizure of mosques and the dissolution of recitation due to differences in schools, views, and religious organizations. The issue of school reference and debate on legal interpretation continues to develop in Aceh to date, even though the formalization of Islamic shariah has taken place through the issuance of a sharia or qanun regulation. Polemics that arise in society even on issues that are not conscientious in Islamic law, for example, are related to the most appropriate procedures for ablution or the law of reading qunut. This means that even though Islam and the Shafi'i school have become the majority religion and school in Aceh and the formalization of Islamic shari'ah has been realized, pluralism in Acehnese society in terms of ideas, views, understandings, and religious principles cannot be ignored. Thus, the issue of tolerance in Aceh is not only in interreligious relations but also in inter-religions.

This article examines Dayah 'ulama's views in Aceh regarding the plurality of religions and the plurality of schools of law in Islam. The opinions of the Dayah 'ulama' are important to study based on their role and position in the Acehnese people's whole life. Dayah is a traditional Islamic educational institution (pesantren), and therefore, its founders and managers are called 'ulama' dayah. Dayah 'ulama' in Aceh play a central role and position in society. As figures who have the capacity in religion, dayah scholars are seen as the heirs or successors of the prophets (waratsatul anbiya) to interpret, teach, and preach Islam (Sjafei, $2007,2)$. The central position of the 'ulama' in society has lasted a long time in Aceh's history. They play various roles outside the religious sphere such as education, politics, economics, and the military. They established and fostered educational institutions, served as sultan advisors / sultanahs during the sultanate, and mobilized resistance through various channels to expel the invaders. After independence, they played a role in filling independence, especially through the education sector, by building and managing dayah as an Islamic educational institution in Aceh. Dayah became a cadre of 'ulama' who played a central role in developing the Muslim community in Aceh (Bustamam- 
Ahmad and Amiruddin, 2013, 57-58). Acehnese 'ulama' are also networked in various 'ulama' organizations. The views of these organizations members and administrators are relevant to understanding the representation of 'ulama' and Acehnese society about plurality and tolerance in Aceh, including in its management.

\section{Position and Role of Dayah 'Ulama' in Aceh}

Before describing the position and role of dayah 'ulama', the understanding of 'ulama' and dayah needs to be explained first. The word 'ulama' has roots with the word 'ilm in Arabic, which means profound knowledge of something (Maluf, 2002, 526.). Therefore, scholars are synonymous with someone who masters science (Huda, 2013, 207). This term in Indonesian absorption then experiences a narrowing of the meaning to mean people who are experts in the science of Islam alone. In the Indonesian context, in general, 'ulama"s title is even obtained by a person not solely because of religious knowledge obtained through formal education, but through public recognition. This recognition results from a long struggle in society in educating and being an example through piety, integrity, noble character, and social responsibility (Iskandariata, 2007, 132-133). In these religious and social functions, 'ulama' occupy the highest strata as a reference for society (Mulkhan, 1994, 167).

Dawam Rahardjo also explained that the predicate of the clergy is a combination of depth in the religious sciences and the quality of oneself and one's dedication, which gives rise to public recognition. In general, scholars' characteristics, namely people who live the religious tradition, have a deep understanding of Islamic law and carry out fiqh law from their knowledge of Islamic law (Rahardjo, 1993, 196). This scientific quality must be accompanied by moral piety and high social responsibility (Rahardjo, 1993, 196). A. Satori Ismail also defines the 'ulama' from several characteristics apart from public belief or recognition, namely: first, always dhikr to Allah; second, always contemplate the creation of the universe; third, stay away from worshiping the thagut. Fourth, surrender to Allah alone. Fifth, not being arrogant, willing to listen to and follow the good opinions of others. Sixth, always impose Allah on and still fulfill everything He taught as contained in the al-Qur'an.

In Acehnese society, 'ulama' are also called teungku and are usually called abi, abu, and walid / waled while their students or students are called aneuk dayah (santri dayah). There are two 'ulama' categories that have developed in Aceh, namely the book 'ulama' and the wetenschap 'ulama'. A book scholar is a scholar who only masters the science of Islam. In contrast, a wetenschap scholar or intellectual scholar is a scholar who masters the science of Islam and general sciences. In the perception of Acehnese society, someone who gets the title of a 
scholar and occupies a special position in the community is someone who has studied Islam in various dayahs so that he has deep religious knowledge and is implemented to teach, lead the community, and become a source of fatwas or opinions on various problems. Which is not limited to only religious issues, but also daily problems (Tosa, 1994,1). Kamaruzzaman Bustamam-Ahmad and M. Hasbi Amiruddin, based on their research, also explained that most Acehnese people think that 'ulama' are people who have studied in the dayah and they lead and own the dayah. Hence there is a dichotomy that develops in society between people looking in dayah and public schools. Dayah is an Islamic scientific and scientific identity. People who study in the dayah are seen as more respectable and have a higher level of Islamic scholarship than those who study in public schools. People who master the science of religion but learn at public educational institutions other than dayah are called modern scholars. This category has a lower meaning than 'ulama' or teungku dayah (Amiruddin, 2002, 119). Modern scholars are at the same level of significance as academics whose roles and positions are limited to formal educational institutions. Based on these definitions, 'ulama' in Aceh are related to people who master Islam's knowledge and maintain Islamic traditions in the dayah (Bustamam-Ahmad and Amiruddin, 2013, 57-58).

The names of 'ulama' or teungku are often juxtaposed with the location of the dayah they lead, for example, Teungku Chik Kutakarang, Abu Tanoh Mirah, Abati Babah Bulouh, Teungku Usman Kuta Krueng, and others. What is interesting is that the nickname of 'ulama' or teungku dayah often uses short names, for example, Waled NU, Waled Hasanon, Tu Sop, Abôn Mukhtar, Tu Bulqaini, Lem Faisal, and others. The nickname with this short name is a form of respect for the 'ulama' or teungku, which reflects the depth of knowledge and the simplicity of his life. Such calls make many Acehnese people who do not know the full and true name of a dayah leader (Syihab, 2010, 62-63). The mention of an 'ulama' or teungku with the location of the dayah they lead also confirms their position, which is very decisive in the continuity and quality of education in the dayah (Ilyas, 2012, 75).

The majority of Acehnese people's view regarding the relationship between 'ulama' and dayah is the same as the general view of the Indonesian people regarding the relationship between kyai or 'ulama' and pesantren. Those who are called kyai or 'ulama' have studied at a pesantren, founded a pesantren, led, or taught at a pesantren. Meanwhile, people who master Islamic religious knowledge and general science, but their teaching and learning activities are not centered in Islamic boarding schools are called academics. So, the characteristics of dayah scholars can be seen based on the character where they study, namely the dayah. Dayah is an autonomous religious education 
institution, built and managed by a teungku chik (Ilyas, 84-86). In Sumatra similar educational institutions are called surau, while in Java and elsewhere, they are called pesantren. There were four models of educational institutions in Aceh during the Sultanate, namely meunasah (SD/diniyah level), rangkang (Tsanawiyah/SMP level), dayah (Aliyah/SMA level). Dayah for high school is divided into dayah balee (academy level) and dayah manyang (university level) (Firdaus, 2019, 85). For santri/santriwati, dayah is a learning platform that guides them to become a generation with Islamic personalities and benefit society. Meanwhile, for 'ulama', through the dayah institution, they play a role as a cultural broker in shaping the socio-religious life of Muslims in Aceh (Burhanuddin, 2012, 74).

The role of the dayah as an Islamic educational institution in Aceh is believed to have been going on since around the 8th century AD. Arab traders and preachers anchored on the coast of Sumatra combined trading and Islamization activities. Dayah was established to accelerate the Islamization process (Firdaus, 75). Historical evidence regarding this matter is still polemic, the same as the polemic among historians about when Islam's arrival began. According to Jajat Burhanudin, dayah development was generally carried out during the reign of Sultan Iskandar Muda in the 17th century. The growth and development of dayah at that time was related to the policy of feudal assimilation, namely the giving of important posts to 'ulama' or teungku as held by uleebalang (little kings). Apart from being related to the aim of strengthening Islam in the sultanate, Iskandar Muda's policy also aimed to form a balance of political power in the uleebalang. On that basis, the establishment of dayahs is generally carried out in the uleebalang jurisdiction called nanggroe. Dayah then spread more widely throughout Aceh to the interior areas. When Snouck Hurgronje came to Aceh at the end of the 19th century, he witnessed the existence of dayah throughout the country with a large and direct influence on the people of Aceh (Burhanuddin, 2012, 75).

The Dutch colonial government attempted to compete with the role of the dayah by introducing the general education system (school) in 1907 (Amiruddin, 2003, 3.). This education system aimed to teach reading and writing in Malay. However, this effort did not get a positive response from the Acehnese people, and even suspected that there were bad Dutch intentions behind the establishment of this educational institution. The Acehnese are not enthusiastic and call it an infidel school. Even more explicitly the 'ulama' in Aceh at that time issued a fatwa prohibiting studying in Dutch schools. The Dutch government wants to train the people of Aceh to be loyal to them through education. This is because, in the view of the Dutch Government, dayah has educated the young generation of Aceh to hate the Dutch (Amiruddin, 2003, 
20).

Since its establishment, especially with the increasing position of the dayah during the Sultanate of Aceh under Iskandar Muda, dayah leaders, namely 'ulama' or teungku played a central role in religious teaching and ensured its correct application in society. They introduced distinctive thoughts and lifestyles to the community, and when the Aceh Sultanate faced disintegrate since the 18th century, Islamic intellectual life shifted to dayah under the 'ulama' or teungku who were previously centered in the sultanate. Dayah even became an important place of coordination and consolidation in the Aceh-Dutch war, which began in 1872 . Thus, the role and central position of 'ulama' or dayah teungku in Acehnese society took place from a long struggle in history. With their mastery of the religious sciences and their long role in Aceh's history, 'ulama' or teungku dayah received wide respect in the community. They are even believed to have the spiritual power to bring blessings and curses and heal and cause pain to someone. Their piety is believed to be a factor in the auspiciousness of their words, which is called karamah or sacred in the guardianship tradition (Burhanuddin, 92).

Even though there have been a series of shifts following the changing times, the Acehnese people still revere the 'ulama' or teungku dayah as pious people and heirs of the prophet who have karamah. So, they must be obeyed. Therefore, the position of 'ulama' or teungku dayah is often heard more by the public than by government officials. In every gampong (village) in Aceh, there are two types of leaders, namely formal and informal. Formal leadership is held by a keuchik (village head) and the 'ulama' or teungku carries out informal leadership. In gampong community life, the kuecik only has administrative authority with a very limited social role. On the other hand, 'ulama' or teunku play a broader social role as religious and customary leaders who become a reference source for solving socio-religious problems. Their position often intersects with political and economic roles (Firdaus, 2019, 32).

According to the dayah tradition in Aceh, the knowledge of a santri or aneuk dayah can be measured based on the number of books that he has studied, and based on the dayah and tengku where he studied. An aneuk dayah can serve his 'ulama' or teungku for years to a dozen years by staying in the dayah. This is a form of devotion shown by a santri to the dayah and 'ulama' or teungku as the supreme teacher who guides in life. In the dayah tradition, there is a tendency to understand that religious knowledge is not solely the result of the students' learning efforts but is owned by being transmitted by 'ulama' or teungku. The concept of scientific blessings as inherent in the pesantren tradition in general also applies in dayah. The knowledge that is blessed is obtained not by studying alone but by being obedient and obedient to the 'ulama' or teungku. Obedience 
and loyalty and the ta'zim attitude of a santri or aneuk dayah to the 'ulama' or teungku often impact reforming views in the religious field. Even if there are ideas for renewal that are proclaimed, such things are seen as foreign and difficult to accept (Syihab, 63-65).

The role and position of the 'ulama' or tengku in the midst of Acehnese society is getting stronger through a network of regional and national organizations in nature. 'ulama' or teungku joined in large organizations at the national level, such as Muhammadiyah, Nahdlatul 'ulama', and Jami'atul Washliyah. Besides, a number of 'ulama' association organizations have also been established in Aceh since before Indonesian independence and have become the embryos for the birth of local Islamic organizations in Aceh. On May 5, 1939, the 'ulama' or teungku joined the All Aceh 'ulama' Association (PUSA). In addition to being intended as a da'wah organization, it was also to build strength against Dutch colonialism. After PUSA's disbandment, a number of 'ulama' or teungku took the initiative to fill the void left by PUSA by establishing the 'ulama' Consultative Assembly (MPU) through a deliberation that took place between 16-18 December 1965 in Banda Aceh. Because the MPU was deemed less independent due to the large number of government parties involved and not all of them were satisfied with the establishment of the organization, several 'ulama' or teungku established a new 'ulama' organization called Persatuan Dayah Inshafuddin, a more specialized organization for gathering 'ulama' or teungku dayah. Apart from Inshafuddin, the 'ulama' organizations that coordinate the dayah groups are the Aceh Taliban Rabithah (RTA) and the Aceh Dayah 'ulama' Association (HUDA). Also, the GAM group, when the separatist conflict was still ongoing, also established an 'ulama' organization called the Nanggroe Aceh 'ulama' Council (MUNA). These Islamic organizations are networks of 'ulama' or teungku who influence the community's socio-religious dynamics through their religious views and opinions and organizational activities.

\section{Plurality and Tolerance}

The word "plurality" is translated from English "plurality," which means diversity, plurality, or plurality. Indonesia uses the idiom of diversity to mean the same thing as a plurality. Bhinneka Tunggal Ika is a sesanti or national ideology underlying the recognition of the plurality of elements that make up Indonesia's unity. Universally, the world is predestined to be made up of different and diverse elements. At a glance, we can see the non-uniformity of things and living things. Likewise, with humans who are physically and psychologically unique to each individual, even the closest biological relationship. To socio-cultural realities, humans are always different because 
they come from various races and ethnicities. Therefore, plurality is the world's reality as it is, so it is impossible to deny it.

This concept is also emphasized firmly in Islam that plurality is a given reality because it is Allah's will (sunnah Allah). God's words in the Qur'an legitimize plurality as an objective reality because humans were created as a nation and with tribes. Al-Qur'an also emphasizes that these ethnic differences are not a reason to emphasize mutually differentiating boundaries. On the contrary, it is precisely to know each other and learn (Q.S. al-Hujurat verse 13 . Allah even compared the plurality of languages (al-sinah) and race (al-alwān) with the creation of heaven and earth (Q.S. al-Rūm verse 22). Recognition in Islam about the necessity of human plurality and the existence of heaven and earth, which was already created from humans. Based on these two words, Allah emphasizes that plurality is His will and demands that humans react positively and play an active role in the provisions for mutual Even about the plurality of religions. Allah gives humans the right to believe deny Him (Romli, 2006, A14).

Meanwhile, in terms of religion, differences can also come from the reality of socio-cultural and individual heterogeneity. Fathi Osman called it the difference between innate and acquired. According to him, religion is between the two differences. That is, religion is a collective inheritance between generations, or it can develop individually. The inherent differences in religion come from the absolutes that each individual must be born in a society with a social system that has been formed, including the belief system. A person who is born into a Muslim family is most likely to become a Muslim. Likewise, a person born into a Christian family will become a Christian. The same applies to people who were born from families with other religions and beliefs. Meanwhile, differences in acquisition originate from the knowledge, understanding, ideas, and information obtained by a person or group of individuals who affect their knowledge of religion and those associated with it. The differences in acquisition also allow individuals or groups of individuals to develop new understandings either from existing religions or fully intellectual creativity. In reality, religious beliefs are generally collective inheritance rather than individually developed. Therefore, diversity in religious beliefs is a necessity that must be accepted in relationships between human beings, which are formed from various socio-cultural backgrounds (Osman, 2012, 1).

Even within one religion, there is no single understanding of its teachings. Interpretation of religious education can vary. Many factors allow for a variety of interpretations. Religious teachings are generally general so that they open up the possibility of various interpretations and understandings in themselves. Also, even religious teachings that are specific in nature can produce different interpretations when they are to be applied to different contexts, times, and 
locations. Therefore, in this context religion can be seen as the source of the emergence of differences in a religious community. In other languages, religion legitimizes differences stemming from the diversity of interpretations of its teachings.

This can be seen in social life in Aceh. Even though Islam is the religion of most Acehnese people, different views on Islamic teachings remain. For example, it is related to differences in schools of thought, differences in worship practices, diversity of religious and community organizations, etc. Even though Aceh has formalized Islamic shari'at into regional regulations (Perda), differences in religious views continue to develop in society. This cannot be avoided because there are many opinions based on the various schools or schools of thought in Islamic law itself. Even in one school, it is not uncommon for different interpretations to appear among his followers. This means that plurality in Aceh does not only come from the side of ethnicity, culture, language, customs, and religion alone because none of these elements is completely uniform. No society is in a vacuum from differences. Significantly when geographic boundaries are increasingly eroded due to technological advances, it is impossible to stop the diversity of viewpoints. Bursting information about a variety of knowledge will open up the chakra of thinking and always open the possibility for the emergence of a variety of views.

Tolerance lies in being patient with different views and philosophical and moral beliefs of others. True tolerance stems from being honest in admitting that one's own opinions and beliefs can be wrong. The demand to be tolerant of others' views and beliefs is not a demand to agree, but rather opens oneself to the potential truth and goodness that comes from others. The essence of tolerance is respect for pluralism and human dignity (Bagus, 2005,1111). Tolerance requires a deep commitment to plurality and human dignity. However, being tolerant does not necessarily mean forcing someone to abandon their judgment that other people's beliefs and practices are of less value. What is opposed in the principles of tolerance is degrading people's value or the dignity of those who embrace a certain belief or practice. A tolerant person respects others, even though they have many differences. They are willing to subjugate the natural human tendency to resist being harsh towards others of different beliefs and practices. A tolerant person usually considers that a fundamental disagreement between himself and another does not necessarily diminish that person's kindness. Even if they disagree with other people's beliefs and practices, tolerant people still value them. On the other hand, an intolerant person accepts humans natural tendency to belittle and belittle others. Thus, tolerance is an attitude that must be maintained to tame one's natural tendency to get rid of others and their beliefs and practices. Therefore, tolerance must be 
a virtue that is developed among religious communities. In terms of inter-and intra-religious relations, tolerance includes five things. First, open to potential truth that comes from other religions and sects. Second, emphasize the existing equations (Dyayadi, 2009, 614). Third, reduce discrimination. Fourth, strengthen a sense of brotherhood as fellow God's creatures and adherents of one religion. Fifth, stay away from attacking practices. Thus, tolerance is an attitude to endure differences in beliefs and opinions as an objective reality and promote positive ways of responding.

\section{The View of Dayah 'Ulama' on Plurality and Tolerance}

The views of dayah 'ulama' on plurality and tolerance in Aceh can a certain extent, indicate a fragment of Acehnese society's social reality. This is because, with their central position and role in society, dayah 'ulama' can represent people's perspectives and attitudes towards various problems. Moreover, in their position and role as religious leaders, dayah 'ulama' have cultural power in formulating a series of concepts, ideas, point of view, and attitudes of the community, especially their followers. According to Abi Syariah, managing plurality in Acehnese society is like using a weapon, which depends on the person using it. When used by open-minded people, the issue of plurality will add to their knowledge and knowledge. Conversely, suppose it is used by people who are narrow-minded and intolerant. In that case, the issue of plurality will result in conflict because it tends to exacerbate differences to attack one another. According to him, currently, the attitude of plurality in Acehnese society tends to be of the second type. Unfortunately, the second type is often more prominent in the media and the wider community. The views that uphold the value of tolerance that is grown in many Islamic dayahs and education are less heard.

Meanwhile, Tu Bulqani, leader of Dayah Ishlah al-Aziziyah and Secretary of the Aceh Dayah 'ulama' Association (HUDA), believes it is not permissible to consider all religions to be true. However, according to Bulqani, Muslims still have to cultivate a tolerant attitude, namely respecting others' beliefs that their religion is true for them. Tu Bulqani also stated that whether someone believes in Allah or they have another god is not really our business as humans. Bulqani emphasized that Allah forbids Muslims to insult or insult others' beliefs because there is no call in Islam to insult the gods of other religions. Rasulullah forbids such an attitude, and this is what is called tolerance. Muslims are required to be balanced in responding to differences in religious teachings. For example, in the matter of the divinity of Prophet Isa or Jesus. Islam firmly rejects the divinity of Prophet Isa or Jesus as believed in Christianity. Islam believes that Prophet Isa or Jesus was one of Allah's messengers (Rasulullah), a servant and not God. 
People who give the Prophet Isa or Jesus the wrong way to glorify him (over ta'zim). Even though Islam's religion has expressed a firm rejection of the divine concept of Christianity, Muslims are still prohibited from insulting and degrading this belief that is shown to Christians (Tu Bulqani, 23 October 2019).

The issue of pluralism and tolerance among religious believers is not prominent in Aceh's social-community life. So far, relations between religious believers are relatively harmonious and harmonious. What becomes a severe problem is an intra-religious relationship, namely the difference in understanding and views among Muslims. Problems in intra-religious relations in Aceh surfaced in several incidents of fighting over mosques, dissolving recitations, and rejecting mosques' construction as described earlier. Muslims carried out these incidents to other Muslims with different views and religious organizations. In highlighting this phenomenon, Tu Bulqani believes that nothing prohibits the Acehnese people from following Islamic schools of thought. Still, the scholars have agreed since Aceh is sovereign that only the Shafi'i school should be followed. Meanwhile, if anyone wants to follow other mu'tabar schools such as the Hanafi school, the Maliki school, and the Hambali school, Acehnese scholars remain open to that desire. For Bulqani, the four schools are ahlu al sunnah wa al jama'ah and the differences that occur are only ijtihadiyah on furu'iyah issues. However, religious understanding and attitudes outside the Shafi'i school must be carried out privately without showing it in front of the general public, let alone trying to gather followers. It is feared that the common people do not understand, let alone some people later consider him heretical. The latter can lead to conflict and division in society.

A similar view was conveyed by Teungku Haji Faisal Ali or who is usually called Lem Faisal, Deputy Chair of the Aceh 'ulama' Consultative Council (MPU). According to Lem Faisal, in the context of Acehnese society, the Shafi'i school has become the main school even though some run other schools in their daily activities. The dominance of the Shafi'i school in Aceh is influenced by the scholars' scientific pedigree, the majority of whom are in the path of the Shafi'i school. In the context of schools other than Shafi'iyah and its relation to intrareligious friction in Aceh, Lem Faisal emphasized that inter-sectarian conflict is a relatively recent phenomenon. This means that the event of friction is related to social, political, and economic problems in the people of Aceh today. Lem Faisal emphasized that the Acehnese people actually have shown flexibility and tolerance in conducting religious views in their daily lives. Lem Faisal gave an example of the practice of buying and selling in coffee shops. In the Shafi'i madhab, the stipulation is that a person must pay in advance for the food and drinks he must consume. However, in the practice of daily life for the people of Aceh who practice Shafi'i, this provision is reversed, namely consuming food 
and drink first and paying for it afterward.

In order to address the issue of different schools of thought in the Acehnese society, which are often related to religious practices, several religious leaders have expressed constructive views. For example, Tengku Sop offers a solution so that understanding of religious tolerance is built through education. According to him, this step is among the best practices that have been practiced by scholars in Aceh, namely by establishing a dayah. As an educational institution, dayah educates the public in the field of religious knowledge, and thus the Acehnese will better understand how to respond to differences that arise in the area of religious understanding. Meanwhile, Teungku Sofyan believes that social conflict due to differences in religious views must be responded to by religious leaders. He even regretted the tendency that society is allowed to be led to differences that lead to conflict. According to Teungku Sofyan, the issue of khilafiyah in fiqh law is intentionally sharpened and repeated at many moments. One of them is the dispute that occurs in every month of Ramadan. A group deliberately harasses the public's comfort in worshiping during the fasting month by exacerbating the problem of differences of opinion regarding the number of rakats in tarawih prayers between 8 or 20 cycles. Other examples of differences in religious practice that are disputed are issues that are not principled in Islamic law, for example, procedures for rubbing the head in ablution or the law of reading qunut (Tu Bulqani, 23 October 2019).

To overcome the sharp differences between religions and intra-religions, $\mathrm{Tu}$ Bulqani suggested that the government make qanuns or regulations to ensure the order as made by the sultan during the previous kingdom. According to Tu Bulqani, the order of Acehnese society was damaged because the government was not too serious in handling disputes in community. According to him, differences that are clearly mistaken should not be tolerated. Meanwhile, Tengku Haji Muhammad Daud Zamzani, commonly referred to as Abu Daud Zamzani, dayah leader Riyadush Shalihin and Chairman of the 'ulama' Consultative Council (MPU), provided several solutions to address the problem of different schools of thought. He emphasized that Aceh is the land of the guardians (auliya), which must be properly guarded. Abu Daud Zamzani's solution is in line with what Tu Sop said that to solve the problem of disputes over religious understanding must be done through education. Abu Daud Zamzani said that Aceh's youth must have deep knowledge, especially in religious knowledge. The hope is that young Acehnese does not become objects of play by other parties. According to him, strong Aceh lies in Acehnese youth who have deep religious knowledge. Young people must have extensive experience, be aware that science will continue to develop, and new things will continue to emerge. Therefore, young Acehnese must be equipped with strong 
religious knowledge to face any new problems, guard Aceh, and guard the people so that Aceh is safe from various polemics and violent conflicts. Intelligent Acehnese children will not get involved in friction due to differences in perspective because they can understand religious differences and practices (Abu Daud Zamzani, 23 October 2019).

As chairman of the MPU, Abu Daud Zamzani also explained that the position of this institution was related to the emergence of problems surrounding differences in mazhab and religious organizations. Abu Daud Zamzani explained that the MPU's efforts were to establish coordination and dialogue with all parties. The role played by the MPU is as a mediator because the MPU is an independent institution that functions to accommodate the various interests of the Muslim community in Aceh (Abu Daud Zamzani, 23 October 2019). The MPU can't take further steps because the MPU is a fatwa body. At the same time, the authority for execution rests with the government and the legislative authority in the Aceh People's Representative Council (DPRA). This has been regulated in Aceh Qanun Number 2 of 2009 article 6 paragraph (1). The qanun explains that the MPU's authority is only to provide input, considerations, and suggestions to the Aceh Government and DPRA in determining any policies taken. Meanwhile, the Deputy Chairman of the MPU, Lem Faisal said that the MPU actually has three powers in dealing with socio-religious issues. First, issue a legal fatwa. Second, recommending rules to the government. Third, the cadre of scholars. For socio-religious issues that require legal opinion, the MPU issues a fatwa, which becomes the basis for the government and legislature in making decisions. To stem new unsettling sects and views, the Aceh MPU has set the criteria for deviance. The fatwas issued by the MPU were accepted by the executive and legislature, as well as the people of Aceh. Meanwhile, for matters that are less urgent and do not require an MPU fatwa, the opinions given by the MPU are in the form of persuasive suggestions.

The various views of the 'ulama' or teungku reflect the mindset in responding and managing issues of plurality and tolerance in Aceh. Some offer solutions that issues of plurality related to differences in religious views and views must be handled wisely. These differences need to be bridged by the 'ulama' or teungku as figures who understand religious sciences and encourage Acehnese people and youth to deepen the religious sciences so that they can understand the basis of the differences that arise. But it is also a view that has a tone of ambiguity. On the one hand, it recognizes that there is plurality in religions and religious understanding and the need for a tolerant attitude towards differences. Still, on the other hand, it limits the presence of religious expressions and practices that are different from the majority so that they are carried out only in the personal and domestic sphere. In this view, on the one hand, individuals are 
allowed to practice different religious understandings and practices. Still, on the other hand, there is pressure to conform, namely assimilating with the dominant group's views and views. Even in the ambiguity of such an idea, there is a tendency to resolve religious understanding disputes with a formal and institutional approach, either through government regulations or 'ulama' organization fatwas.

\section{Conclusion}

The issues of pluralism and tolerance in Aceh show a new dynamic. Apart from being related to the diversity of ethnic, racial, and religious backgrounds, Aceh's people also live between different Islamic understandings and views. In recent developments, differences and distinctions based on the practice of worship, mazhab, and Islamic in traumatic religious organizations are even more prominent than in inter-religious relations. Intra-Muslim differences and distinctions have even led to disputes and conflicts with violent nuances such as the dissolution of recitations and the struggle for worship places. A phenomenon like this reflects that the socio-religious reality in Aceh, on the one hand, is not uniform, let alone singular and, on the other hand, shows the existence of problems in the management of tolerance. Despite the formalization of Islamic shari'ah through qanuns or local regulations, differences in Islamic teachings continue to grow in society. This also shows that the understanding of Islam in Aceh remains dynamic to some degree. However, the continued pattern of differences in religious understanding leads to negative ways and shows a trend towards Aceh's tolerance levels.

The 'ulama' or teungku dayah as religious leaders gave a religious response to the reality of pluralism and tolerance in Aceh. Some of them emphasized that diversity must be respected and respected. This is a tolerant view of the pluralistic reality. But on the other hand, there is also the view that differences should ideally be suppressed at the lowest level. The ideas and practices of religious minorities are encouraged to operate at the individual and domestic levels to not disturb the stability of the dominant religious views and practices. Regarding the disputes that occurred, the 'ulama' or teungku dayah and religious organizations in Aceh offered various solutions. Some encourage the need for broader education in the religious sciences for Acehnese youth. In contrast, others promote the use of formal approaches through the making of qanuns or government regulations and an institutional approach through clerical organizations. 
Journal of Islamic Thought and Muslim Culture (JITMC), 2 (2), 2020|187

\section{References}

Books and Journals

Abubakar, Marzuki, 2011. "Syariat Islam Di Aceh, Sebuah Model Kerukunan dan Kebebasan Beragama”, Media Syari'ah, 3 (1).

Amiruddin, M. Hasbi, 2002. "'ulama' Dayah: Peran dan Responnya Terhadap Pembaruan Hukum Islam," Dody S.Truna and Ismatu Ropi, eds., Pranata Islam Di Indonesia, Jakarta: Logos Wacana Ilmu.

Bagus, Lorens, 2005. Kamus Filsafat, Jakarta: Gramedia Pustaka Utama.

Burhanuddin, Jajat, 2012. Ulama dan Kekuasaan, Jakarta: Mizan Publika.

Bustamam-Ahmad, Kamaruzzaman and Amiruddin, M. Hasbi, 2013, 'ulama', Separatisme dan Radikalisme di Aceh, Yogyakarta: Kaukaba bekerjasama dengan LSAMA.

Bustamam-Ahmad, Kamaruzzaman and Amiruddin, M. Hasbi, 2013, 'ulama', Separatisme dan Radikalisme di Aceh, Yogyakarta: Kaukaba bekerjasama dengan LSAMA.

Dyayadi, M.T., 20og. Kamus Lengkap Islamologi, Yogyakarta: Qiyas.

Firdaus, 2019. "Peran Organisasi Teungku Dayah dalam Pelaksanaan Syariat Islam di Aceh", Desertasi, Program Studi S3 Aqidah dan Filsafat Islam Pascasarhana UIN Sumatera Utara.

Huda, Nor, 2013. Islam Nusantara, Sejarah Sosial Intelektual Islam di Indonesia, (Yogyakarta: Ar-Ruzz Media.

Ilyas, Mukhlisuddin, 2012. Pendidikan Dayah di Aceh Mulai Hilang Identitas, Yogyakarta: Pale Indonesia Media.

Iskandariata, Anita T., 2007. Makna Hikayat Perang Sabil di Aceh (Banda Aceh: Ar-Raniry Press IAIN Ar-Raniry Darussalam bekerjasama dengan AK-Group Yogyakarta.

Ismail, A. Satori, 2012. "Ciri 'ulama”, Harian Republika, Selasa, 9 Oktober.

Ma'luf, Lois, 2002, Qamus al-Munjid, Beirut: Dar al-Masyriq.

Mulkhan, Abdul Munir, 1994. Runtuhnya Mitos Politik Santri, Strategi Kebudayaan dalam Islam, Yogyakarta: Sipress.

Osman, Mohamed Fathi, 2012. Islam, Pluralisme dan Toleransi; Pandangan alQur'an, Kemanusiaan, Sejarah, dan Peradaban, Jakarta: Democracy Project.

Rahardjo, Dawam, 1993. Intelektual Inteligensia dan Perilaku Politik Bangsa Risalah Cendikiawan Muslim, Mizan: Bandung.

Rahardjo, M. Dawam, 1993. Intelektual Inteligensia dan Perilaku Politik Bangsa Risalah Cendikiawan Muslim, Mizan: Bandung.

Rahardjo, M. Dawam, 1996. Ensiklopedi al-Qur'an, Jakarta: Paramadina.

Romli, Mohamad Guntur, 20o6. "Al-Quran, Natal, dan Pluralisme Agama", Irwan Suhanda, ed, Damai untuk Perdamaian, Jakarta: Kompas Media Nusantara.

Sjafei, M. Saleh, 2007. "Studi Tentang Persepsi Masyarakat Aceh Terhadap 
Ulama Perempuan", Laporan Penelitian, Universitas Syiah Kuala, Banda Aceh.

Suyanta, Sri Suyanta, 2008. Dinamika Peran Ulama Aceh, Banda Aceh: Ar-Raniry Press.

Syihab, Mahdi, 2010, "Penegakan Syariat: Etnografi Aksi Razia Santri Dayah di Aceh Utara", dalam Arskal Salim dan Adlin Sila, eds., Serambi Mekkah yang Berubah, Jakarta: Pustaka Alvabet bekerjasama dengan Aceh Research Training Institute.

Tosa, A. Halim, 1994. "Ulama Menurut Persepsi Masyarakat Aceh", Laporan Penelitian, Darussalam-Banda Aceh: Pusat Penelitian dan Pengabdian pada Masyarakat IAIN Ar-Raniry.

Interviewed

Abu Daud Zamzani, Islamic Public Figure.

Tu Bulqani, Islamic Public Figure. 